\title{
Derbent İlçesi (Konya) Topraklarının Özellikleri ve Sorunları Üzerine Bir Değerlendirme
}

\author{
Recep Bozyiğit ${ }^{1 *}$ \\ ${ }^{1}$ Necmettin Erbakan Üniversitesi, Ahmet Keleşoğlu Eğitim Fakültesi, Coğrafya Eğitimi, Konya, Türkiye (ORCID:0000-0002-9790-1168).
}

(İlk Geliş Tarihi 08 Mayıs 2020 ve Kabul Tarihi 17 Haziran 2020)

(DOI: 10.31590/ejosat.734209)

\begin{abstract}
ATIF/REFERENCE: Bozyiğit, R. (2020). Derbent İlçesi (Konya) Topraklarının Özellikleri ve Sorunları Üzerine Bir
\end{abstract} Değerlendirme. Avrupa Bilim ve Teknoloji Dergisi, (19), 505-514.

Öz

Derbent İlçesi Topraklarının Özellikleri ve Sorunları Üzerine Bir Değerlendirme adlı çalışma yöredeki toprak tiplerini, özelliklerini ve toprakların karşı karşıya kaldığı sorunları ortaya çıkarmayı hedeflemektedir. Farklı tarihlerde gerçekleşen arazi çalışmalarında toprak özelliklerine yönelik gözlemlerde bulunulmuş, ilçe topraklarının ilçe tarım müdürlüğü tarafından yapılmış laboratuvar analizleri değerlendirilerek bir takım bulgulara ulaşılmıştır.

Derbent ilçesi toprakları, pedogenetik özelliklerine göre yapılan sınıflamada üst kategori tasnifine tabi tutulmuştur. Buna göre yörede altı büyük toprak grubu yer almaktadır. Bu topraklardan en yaygın olanı, kırmızımsı kestane rengi topraklarıdır. Bunu kestane rengi, kireçsiz kahverengi orman, kolüvyal, alüvyal ve kırmızımsı kahverengi toprakları takip eder.

İlçe topraklarında ana kaya, iklim ve topoğrafyanın etkileri görülmektedir. Volkanitlerin yaygın olduğu sahalarda kireçsiz kahverengi orman, kireçtaşının yaygın olduğu yerlerde kırmızımsı kestane rengi toprakları, topoğrafyanın düz veya hafif eğimli yerlerinde alüvyal ve kolüvyal topraklar yer alır.

Derbent ilçesinin farklı yerlerinden alınan toprak örneklerinin laboratuvar analizlerinde: saturasyon \%31-73.7, toplam tuz 0.00-0.03, pH 7.5-7.8, kireç $\left(\mathrm{CaCO}_{3}\right)$ 1.4-15.2, fosfor $\left(\mathrm{P}_{2}{ }_{2} \mathrm{O}_{5}\right)$ 1.26-22.0, Potasyum $\left(\mathrm{K}_{2} \mathrm{O}\right), 48.60-154.46$ organik madde 1.26-2.09 arasında değişmektedir. İlçe topraklarında; tuzluluk ve alkalilik probleminin olmadığı, kireçli, potasyum miktarının yeterli, organik maddenin az olduğu sonucuna ulaşılmıştır. Bu sonuçlara göre ilçede yetiştiriciliği yapılan fasulye, patates, çilek tarımı için makro ve mikro besin elementi takviyesi yapılması zorunludur.

Derbent ilçesi topraklarını tehdit eden süreçler arasında; erozyon, sulama, sığlık, eğim, taşlılık, yanlıs arazi kullanımı dikkati çekmektedir. İlçe toprakların karşı karşıya kaldığı bu problemlerin çözümünde gerekli yatıımların yapılması yanında yöre insanına toprak potansiyeli kavratılmalı, daha sonra da bu değerleri koruyarak kullanma yolu öğretilmelidir.

Anahtar Kelimeler: : Derbent, Toprak, Fiziksel, Kimyasal, Özellik.

\section{An Evaluation on the Properties and Problems of Derbent District(Konya) Soils}

\begin{abstract}
This study aims to reveal the types, properties and the problems of the soil in the Derbent District, where studies were conducted on different dates, observations were made regarding the soil properties, and some findings were obtained by evaluating the laboratory analyzes made by the district agriculture directorate of the district lands.

He study utilized upper category classification regarding the pedogenetic features. There were six large soil groups in the region. The most common of these soils are reddish maroon soils. This is followed by chestnut, lime-free brown forest, colluvial, alluvial and reddish brown soils.

The effects of the bedrock, climate and topography can be seen on the territory of the district. The areas where volcanics are widespread include lime-free brown forest, reddish maroon soils where limestone is common, alluvial and colluvial soils in flat or slightly sloping areas of the topography.
\end{abstract}

\footnotetext{
* Sorumlu Yazar: Necmettin Erbakan Üniversitesi, Ahmet Keleşoğlu Eğitim Fakültesi, Coğrafya Eğitimi, Konya, Türkiye, ORCID:0000-0002-9790-
} 1168, fethiye.kemer@gmail.com 
In laboratory analyzes of soil samples taken from different parts of Derbent District: saturation 31-73.7\%, total salt $0.00-0.03$, pH 7.57.8, lime $\left(\mathrm{CaCO}_{3}\right)$ 1.4-15.2, phosphorus $\left(\mathrm{P}_{2} \mathrm{OO}_{5}\right)$ 1.26-22.0, Potassium $\left(\mathrm{K}_{2} \mathrm{O}\right)$, 48.60-154.46 organic matter ranges from 1.26 to 2.09.

It is concluded that there is no salinity and alkalinity problem, calcareous, potassium amount is sufficient and organic matter is low. According to these results, it is compulsory to make macro and micronutrient supplements for the cultivation of beans, potatoes and strawberries cultivated in the district.

Among the processes that threaten the territory of Derbent District, the following are attention taking: erosion, irrigation, shallowness, slope, stoniness, wrong land use. In addition to making the necessary investments in solving these problems faced by the district lands, the local people should be taught the potential of the soil and then they should be taught how to use them by preserving these values.

Keywords: Derbent, Soil, Physical, Chemical, Feature.

\section{Giriş}

Toprak; oluşumu, özellikleri, kullanım ve korunması ile her zaman insanların dikkatini çekmiştir. Toprak, "üzerinde ve içinde geniş bir canlı âlemini barındıran, bitkilerin durak yeri ve besin kaynağı olan ve belirli oranda katı, sıvı, gaz içeren maddeler topluluğunun genel adıdır" şeklinde tanımlamaktadır (Akalan, 1983). Toprağı oluşturan faktörler ile ilgili farklı görüşler olmasına karşın (Dokuchaev, 1886; Jeny, 1941; Crocker, 1952; Mückenhausen, 1962) ortak görüş iklim, ana materyal, topoğrafya, canlılar ve zamandır (Mater, 1998: 14-15; Efe, 2010:179). Bunlardan ana materyal, topoğrafya ve zaman pasif; iklim ve canlılar ise aktif faktörlerdir (Efe, 2010:179).

Toprak oluşumundaki etkili olan faktörlerin yeryüzündeki etkileri de farklı olmaktadır. Bu duruma bağlı olarak toprak tipleri ortaya çıkmaktadır. Toprak tiplerini ortaya koyan çeşitli sistemlerin geliştirildiğini görmekteyiz (Dokuchaev, 1882-1900; Marbut, 1927; Baldwin, M-Kellog,C.E.-Thord, J.,1938; FAO ve UNESCO, 1971-1981; Atalay, 2011; Atalay, İ.-Gökçe Gündüzoğlu, A.,2015). Derbent ilçesi toprakları ise pedogenetik ve fiziksel özelliklerini esas alan üst kategoride; büyük toprak grupları düzeyinde adlandırılarak incelenmiştir (T.C. Tarım ve Orman Bk., Topraksu Gn. Müd.1992:2).

Toprak örtüsünün kaldırılması, buradaki bitki örtüsünün de bozulmasına ve dolayısıyla topoğrafik yapının değişmesine neden olmaktadır. Bu da doğal dengenin bozulmasına yol açmaktadır (Özdemir, S.1997:135-136). Toprak değişkenliği farklı zaman ve mekân ölçeğinde etkili olan doğal ve antropolojik süreçlerin bir sonucudur. Topraklardaki bu doğal değişkenlik, jeolojik ve toprak oluşum süreçlerinden kaynaklanmaktadır (Efe, 1999). Antropojenik değişkenlik ise insanların arazi kullanımının bir sonucu olarak ortaya çıkmaktadır.

Toprak kaynakları potansiyelinin korunmasında en önemli konu mevcut durumun tespiti ve ileri projeksiyona yönelik tutumların saptanarak alınabilecek önlemlerin ortaya konulmasıdır (Bağdatlı, M.C.-İstanbulluoğlu, A.-Bayar, N.A. 2014: 17). Toprakları koruma ve kullanma, toprağın özelliklerini iyi kavramaktan geçer. Bu açıdan Derbent ilçesi toprakları araştırma konusu olarak seçilmiştir. Derbent ilçesi, Konya il merkezinin batısında yer almaktadır. İlçe merkezi, 38 $00^{\prime} 48^{\prime \prime}$ kuzey enlemi, 32 $00^{\prime} 55^{\prime \prime}$ doğu boylamı üzerinde bulunmaktadır. Yüzölçümü 359,0 km² dir. İlçenin kuzeyinde Ilgın, kuzeydoğu ve doğusunda Selçuklu, güneydoğusunda Meram, batı ve güneybatısında Beyşehir ilçesi yer almaktadır (Harita 1). İlçede önceki yıllarda köy, belde, mahalle statüsünde olmak üzere 13 mahalle yerleşmesi bulunmaktadır.

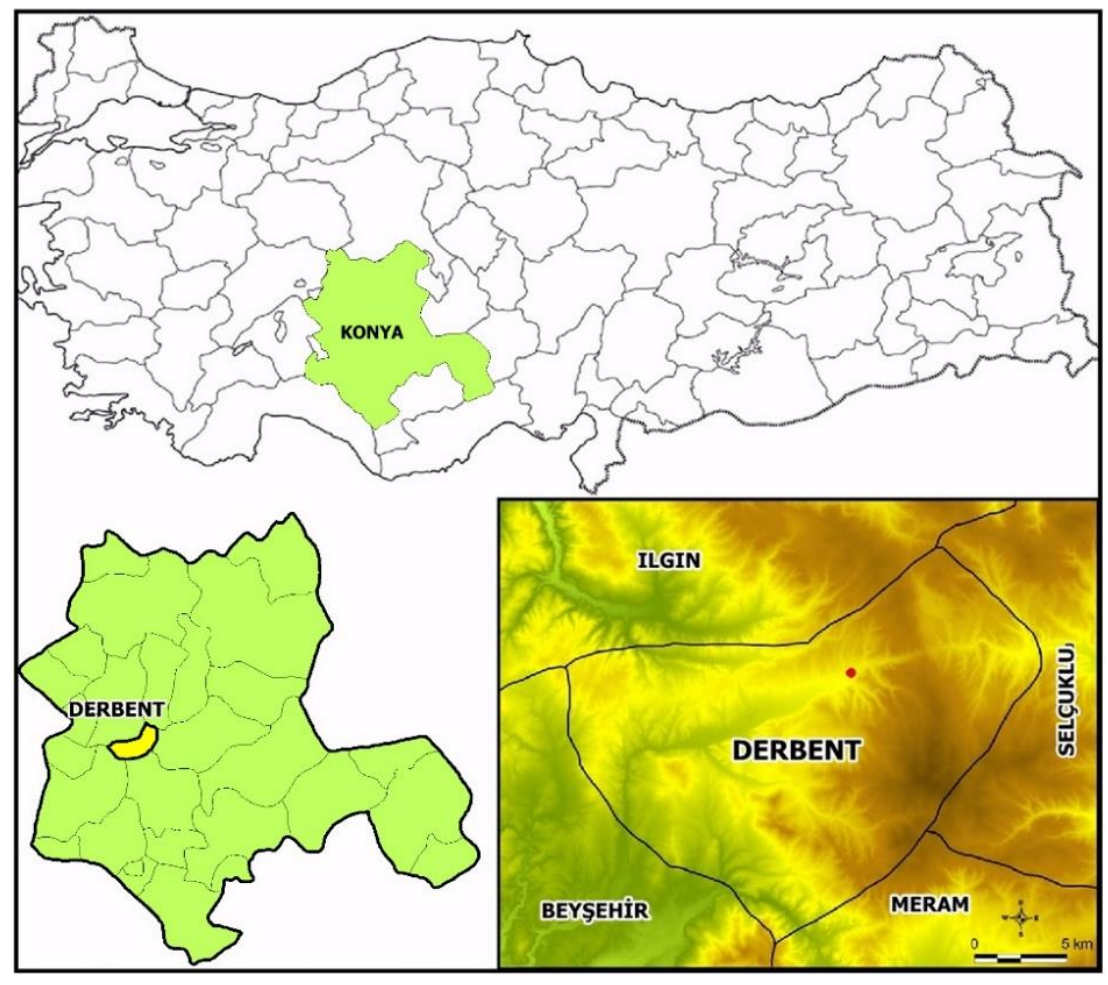

Harita 1. Derbent İlçesinin Lokasyon Haritası 


\section{Materyal ve Metot}

Derbent İlçesi Topraklarının Özellikleri ve Sorunları Üzerine Bir Değerlendirme konulu çalışmada esas metot, gezi gözlem metodu olmuştur. Farklı tarihlerde gerçekleşen arazi çalışmalarında toprak özelliklerine yönelik gözlemler ve Derbent İlçe Gıda Tarım ve Hayvancılık Müdürlüğü tarafından yaptırılmış toprak analizleri dikkate alınarak bir takım bulgulara ulaşılmıştır. Daha sonra elde edilen bulgular ve Topraksu Genel Müdürlüğü tarafından hazırlanan haritalar 1şığında Derbent ilçesinin toprak özellikleri ve sorunlarının tespitine yönelik bu çalışma hazırlanmıştır.

Bu çalışmada: 1/100 000 topoğrafya haritalarının Ilgın L 27, Konya M 27, M 28 ile 1/25 000 ölçekli Ilgın L27 ( $c_{3}$, c 4 ), Ilgın L28 $\left(\mathrm{d}_{3}, \mathrm{~d}_{4}\right)$, Konya M $27\left(\mathrm{~b}_{1}, \mathrm{~b}_{2}\right)$, Konya M 28( $\left.\mathrm{a}_{1}, \mathrm{a}_{2}, \mathrm{~b}_{1}, \mathrm{~b}_{2}, \mathrm{~b}_{3}, \mathrm{~b}_{4}\right)$ paftaları; 1/100 000 ölçekli Türkiye Jeoloji Haritasının Konya M 27, M 28 (Şenel-Dalkılıç, 2016; Şenel-Pehlivan, 2016) paftaları ve büyük toprak tiplerinin dağılışını gösteren T.C. Tarım Orman ve Köy İşleri Bakanlığı, Topraksu Genel Müdürlüğü’nün (1992), 1/100 000 ölçekli haritasının ilgili paftaları kullanılmıştır.

\section{Araştırma Sonuçları ve Tartışma}

\subsection{Toprak Özelliklerini Etkileyen Faktörler}

Derbent ilçesini oluşturan arazide Üst Permien olarak adlandırılmış kristalize kalker, kalker ve mermerler üzerine Trias yaşlı birimler konkordant olarak gelmiştir. Miosen-Pliosen çökelleri ise birbirleri ile uyumlu olarak alttaki birimleri diskordant olarak örtmüştür (Şenel-Dalkılıç, 2016; Şenel-Pehlivan, 2016). Holosen yaşlı alüvyonlar ise en üstte yer alır. İlçe sahasında karbonatlı kayaçların fazlalığı toprakların kireçli olmasında etkili olmuştur. Derbent ilçesini oluşturan arazi Alp Orojenezi ve devamındaki epirojenik hareketlerden etkilenerek kıvrımlı ve kırıklı bir yapı özelliği kazanmıştır.

Derbent ilçesinin yer aldığı sahada ana yeryüzü şekilleri arasında dağlık ve platoluk araziler geniş yer kaplamaktadır. Dağlık sahalar, ilçesinin doğu kesiminde yer almaktadır (Harita 2). Dağlık sahalar içerisinde de kütlevi bir özellik gösteren Aladağ en dikkati çekendir. Plato sahası, Derbent ilçesinin batı kesiminde kuzeyden güneye doğru daralarak uzanmaktadır. Kuzeyde Derbent Deresi'nin oluşturduğu vadinin kuzeyi ve güneyinde Miosen-Pliosen yaşlı kalker marn, konglomera ve kumtaşları plato sahasının ana yapısını oluşturmaktadır. Platoyu oluşturan birimler yatay konumludur. Bu durum, erozyonu azaltıcı yönde etkili olmaktadır. İlçede diğer yeryüzü şekli vadilerdir. Derbent Deresi Vadisi'nin Akdağ’’n batı kesiminde yer alan kısımları ile Bağırsak Boğazı'nın çevresinde; akarsu ve yüzey erozyonunun etkili olduğu görülmektedir. Bu kesimlerde çıplak kayalıklar ve yer yer peribacası oluşumları dikkati çekmektedir.

Derbent ilçesinin en yüksek kesimleri, doğusunda bulunmaktadır (Harita 2). İlçenin doğu kesiminde kuzeyden güneye doğru Tasmakıran T.(1856 m), Aladağ (2339 m) ve Sarı T.(2040) yer almaktadır. Bu yüksek kesimin batıya doğru uzantısını Dikmen T.(1762 $\mathrm{m}$ ) oluşturmaktadır. Bu kesimlerde eğim $11^{\circ} 18^{\prime} 35^{\prime \prime}$ ile $30^{\circ} 57^{\prime} 49^{\prime \prime}$ arasında değişmektedir. Toprak oluşumunun son derece yavaş olduğu bu kesimlerde, genellikle çıplak kayalık yüzeyler dikkati çeker. İlçenin batı kesimleri, Derbent ve Bağırsak dereleri tarafından yarılmış dalgalı plato özelliği göstermektedir. Yer yer tek tepelerin yer aldığı plato sahasında eğim değerleri $02^{\circ} 51^{\prime} 44^{\prime \prime}$ ile $05^{\circ} 42^{\prime} 38^{\prime \prime}$ arasında değişmektedir. Bağırsak Deresi'nin vadi yamaçlarında eğim yer yer $11^{\circ} 18^{\prime} 35^{\prime \prime}$ dereceyi bulmaktadır. Eğimin en az olduğu sahalar; Arapözü-Süleyman arasındaki Derbent Deresi Vadi tabanıdır. Eğim buralarda da $00^{\circ} 00^{\prime} 00^{\prime \prime}$ ile $02^{\circ} 51^{\prime} 44^{\prime \prime}$ arasında değişmektedir. Eğimin az olduğu kesimlerde alüvyal ve kolüvyal topraklar görülmektedir.

Derbent ilçesinin batı kesiminde karasal iklime geçiş özelliğine sahip iklim görülürken, doğu kesiminde Aladağ ve yüksek rölyefin etkisi ile karasal iklim etkili olmaktadır. Yörede yağışlar alçak sahalarda yağmur, yüksek dağlı alanlar ile iç bölgelerde kar şeklindedir. İlçede yıllık ortalama sıcaklığın $10-10.8{ }^{\circ} \mathrm{C}$, arasında (Beyşehir $10.8{ }^{\circ} \mathrm{C}$, Derbentte $10.0{ }^{\circ} \mathrm{C}$ ) ve yıllık toplam yağışın $505.0-515.6 \mathrm{~mm}$ arasında değiştiği (Beyşehir, $505.0 \mathrm{~mm}$, Derbent $515.6 \mathrm{~mm}$ ) tespit edilmiştir (D.M.İ.Gn.M.,2016). Rüzgâr yönü mevsimlere göre değişmekle beraber hakim rüzgâr yönü doğu sektörlüdür. İklimin ilçe toprakları üzerindeki en önemli etkisi yağış azlığı bağgl kuraklıktır.

İlçe topraklarının bugünkü özellikleri kazanmasında etkili olan bir diğer unsur da hidrografik faktörlerdir. Hidroğrafik unsurlar içerisinde Derbent (Saracık), Uluçay ve Bağırsak (Çokasuyu) derelerinin etkileri görülmektedir. Uluçay ve Derbent derelerinin kaynağı Aladağ'ın yüksek kesimleridir. Derbent Deresi ve kollarının, toprakların kum oranının fazlalığında, alüvyal toprakların oluşumu ve su erozyonunda etkili olduğu sonucuna ulaşılmıştır.

Derbent ilçesi ve çevresinde yarı nemli iklim şartlarına uyum sağlamış vejetasyon tipleri görülmektedir. Vejetasyon tipleri: step, çalı ve orman vejetasyonu şeklinde sınıflandırılabilir. Bu vejetasyon tipleri genellikle sekonderdir. Step vejetasyonunda; Pelin (Artemisia santonicum), Geven (Astragalus angustifolius), Parlak Geven (Astragalus nitens), Sipil kekiği (Thymus sipyleus), Üzerlik (Peganum harmala) dikkati çeken türlerdir. Çalı vejetasyonu da orman formasyonunun kenarlarında ve orman içi açıklıklarda, ağaçlandırma sahalarında ve step sahalarında bazen topluluk bazen de münferit olarak yayılış göstermektedir. Çalı formasyonu içerisinde; Alıç (Crataegus orientalis), Yabangülü (Rosa canina), Böğürtlen (Rubus discolor), Keçi bademi (Amygdalus orientalis), Muşmula (Cotoneaster nummularia), Ahlat (Pyrus elaeagnifolia), yaygın olan türlerdir. Orman vejetasyonu, 1300-2000 metreler arasında step ormanı özelliği taşımaktadır. Meşe-ardıç karma ormanları, Değiş Mahallesi’nin doğu ve batısında özellikle de Aladağ'ın (2339 m) güneydoğu ve güneybatı yamaçlarında yaygındır(Bozyiğit-Kaya, 2017:163). 


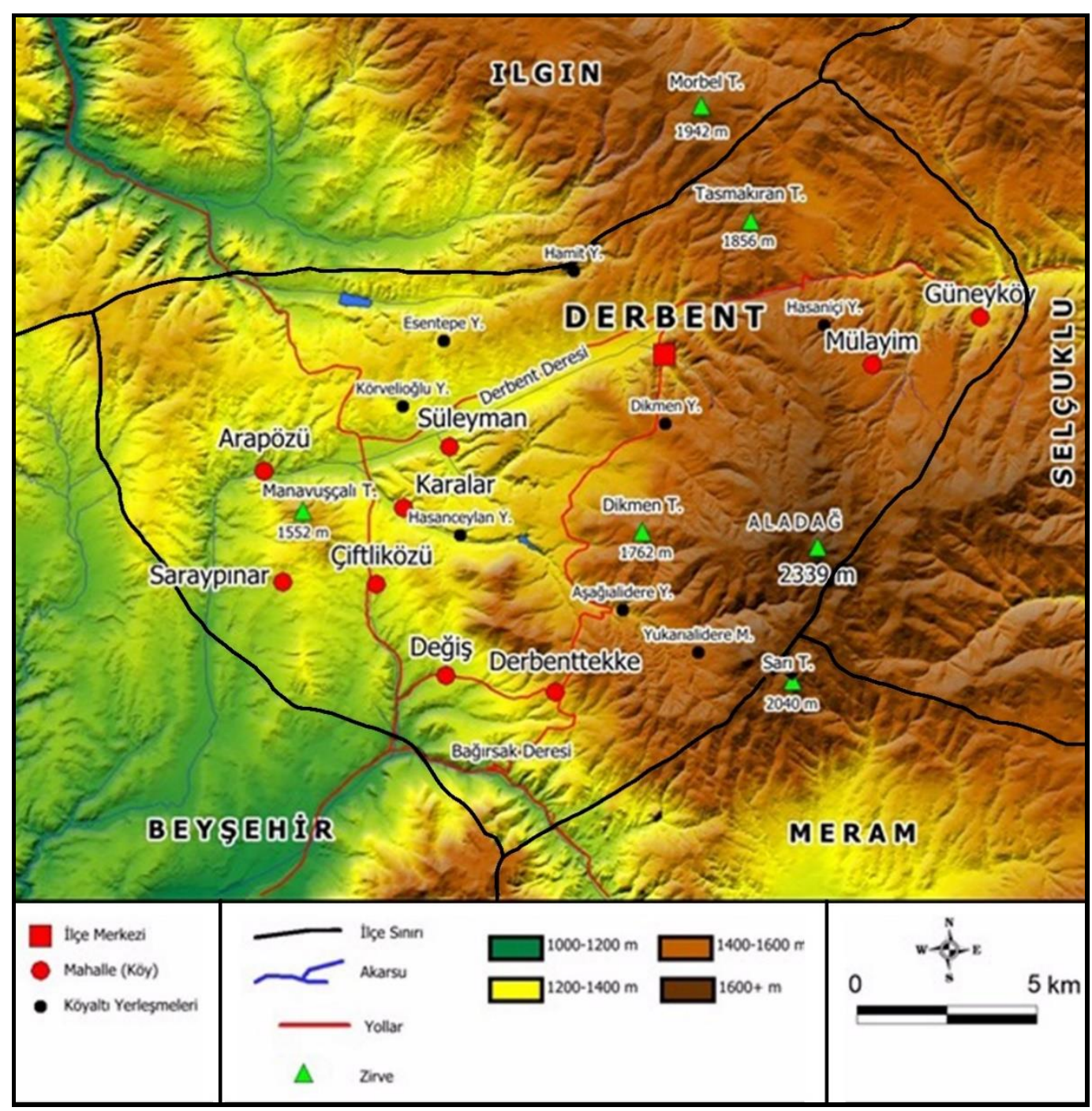

Harita 2. Derbent İlçesinin Yeryüzü Şekilleri Haritası

Derbent ilçesi topraklarında, 2019 yılı sonunda 13 mahalle yerleşmesinde toplam 4267 kişi (TÜiK, 2020) yaşamaktadır. Bu nüfusun geçim kaynakları arasında tarım ve hayvancılık önemli yer tutmaktadır. İlçede toplam arazinin \%38.04'ü (138 $000 \mathrm{da})$ tarım, \% 32.03’ü (116360 da) orman, \% 1.9’u (6 850 da) çayır-mera ve \%28.03’ü (362 976 da) diğer arazilerden oluşmaktadır (TÜiK, 2016: T.C. Derbent Kaymakamlı̆̆ı̆, Derbent İlçe Gıda Tarım ve Hayvancılık Müdürlüğü, 2017, 2018). Tarım arazilerinin büyük çoğunluğu Derbent Deresi vadi tabanı ile alçak plato yüzeylerinde yer almaktadır. Ancak vadi yamaçlarında yer alan Mülayim, Güneyköy, Süleyman, Karalar, Çifliközü, Arapözü, Değiş, Derbenttekke mahallelerinin tarım faaliyetleri, orman ve çayır-mera arazisi üzerinde baskı oluşturmaktadır.

Günümüzde Derbent ilçesi topraklarının karşı karşıya kaldığı sorunlar arasında erozyon, sığlık, taşlılık ve arazi kullanımındaki yanlışlıklar yer almaktadır.

\subsection{Toprak Tipleri ve Özellikleri}

Derbent ilçesindeki topraklar, pedogenetik özelliklere göre yapılan sınıflamada üst kategori tasnifine tabi tutulmuştur. Üst kategori tasnifi büyük toprak grubu seviyesinde olmuştur. Tasnifi yapılan büyük toprak gruplarının fiziksel ve kimyasal analizlerine göre bölge topraklarının genel karakterleri tespit edilmiştir. Buna göre Derbent ilçesindeki toprakların çoğunluğu tortul ve volkanik kütlelerin ayrışması sonucu teşekkül etmişlerdir. Sahada 6 büyük toprak grubu mevcuttur. Bunlar: alüvyal, kolüviyal, kestane rengi, kırmızımsı kestane rengi, kırmızımsı kahverengi ve kireçsiz kahverengi orman topraklarıdır (Harita 3).

\subsubsection{Alüvyal Topraklar}

Bu topraklar, A ve C horizonuna sahip akarsu ve göl rejimli depozitlerin meydana getirdiği ve farklı zamanlarda meydana gelen, sedimantasyon durumuna göre profilinde çeşitli katlar bulunan genç ve derin topraklardır. Akarsular tarafindan teşekkül ettirilen alüvyonlar; Derbent (Saracık) ile Belbaşı derelerinin vadi tabanları ve taraçalarında görülmektedir (Harita 3; Fotoğraf 1). Geçirgenlikleri normal, iyi drenajlı, tuzluluk ve alkalilik problemi olmayan bu topraklarda, sulu tarım yapılmaktadır. Kısmen bu topraklarda bahçe bitkileri yetiştirilmektedir. 


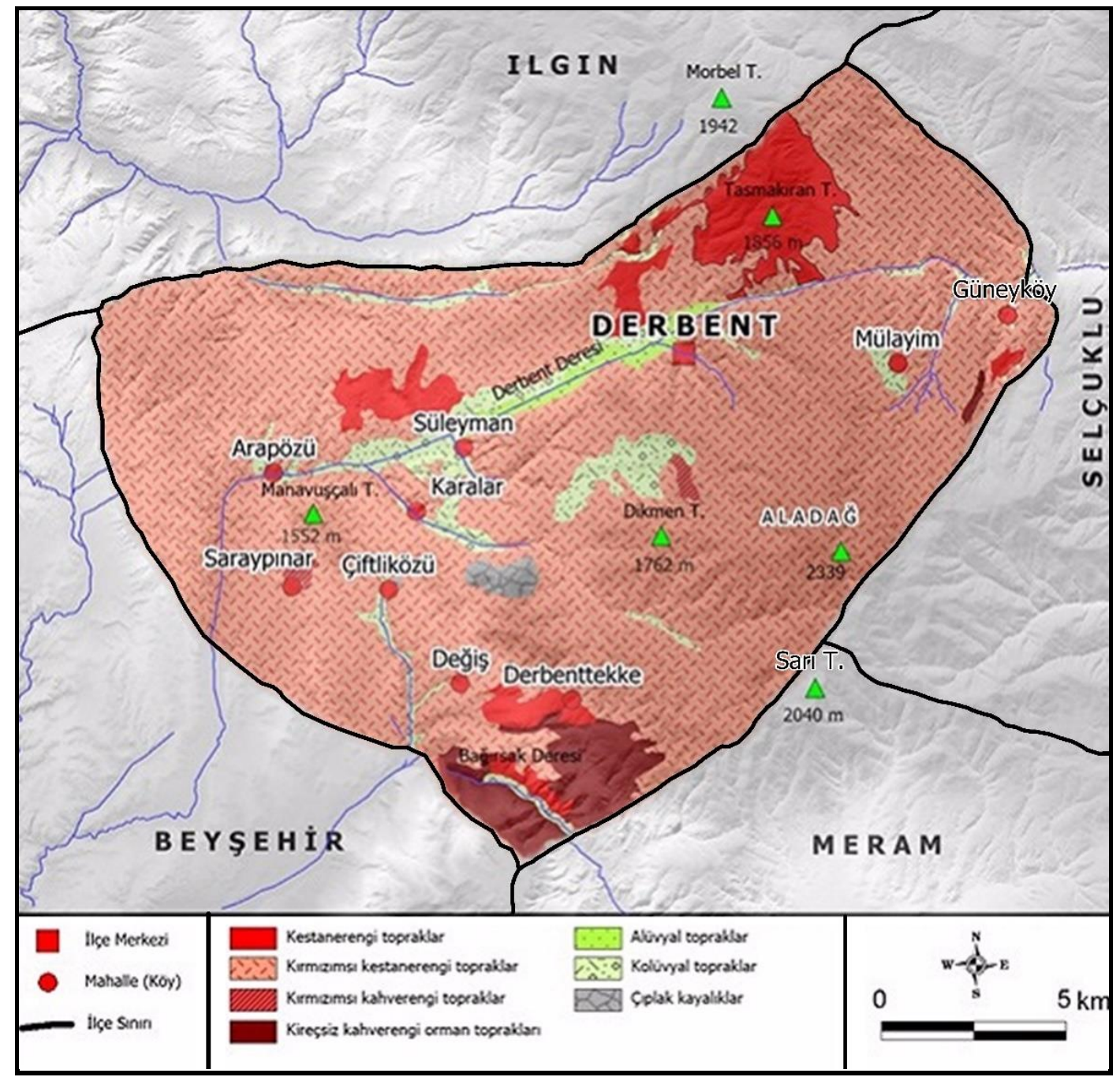

Harita 3. Derbent İlçesinin Toprak Haritası (Konya İli Arazi Varlığı, 1992 'den Değiştirilerek)

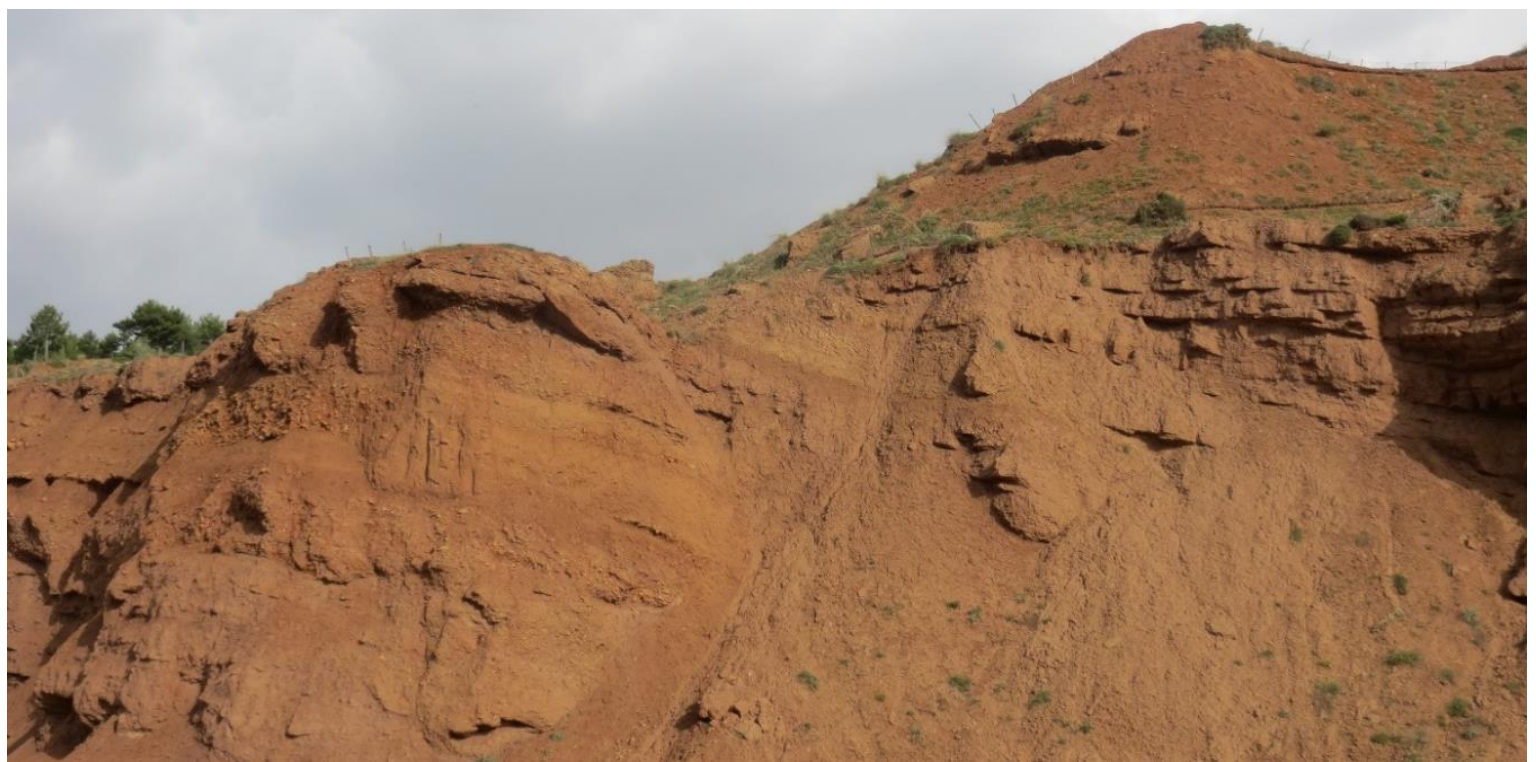

Fotoğraf 1. Derbent Deresi Vadi Tabanı ve Yakınındaki Taraçada Kesit Vermiş Alüvyal Topraklar.

Bu toprakları karakterize etmesi açısından Yukarı ve Camiikebir mahallelerinin farklı yerlerinden alınan toprak örneklerine göre: Yukarı Mahalle topraklarının: tınlı, tuzsuz, hafif alkali, kireçli, fosfor ve potasyum miktarları yüksek, organik maddenin az olduğu tespit 
edilmiştir. Camiikebir Mahallesi topraklarında ise kili-tın, tuzsuz, hafif alkali, kireçli, fosfor miktarı çok yüksek, potasyumun yeterli, organik maddenin ise az olduğu sonucuna ulaşılmıştır (Tablo 1).

Tablo 1. Derbent İlçe Merkezinde Yer Alan Yukarı ve Camiikebir Mahallesi Mevkilerinden Alınan Toprak Örneklerine Ait Bazı Özellikler**

\begin{tabular}{lccccccc}
\hline $\begin{array}{l}\text { Toprak Örneği } \\
\text { Alınan Yerler }\end{array}$ & Saturasyon & $\begin{array}{c}\text { Toplam } \\
\text { Tuz }\end{array}$ & $\mathbf{p H}$ & $\begin{array}{c}\text { Kireç } \\
\left(\mathbf{C a ~ C O}_{\mathbf{3}}\right)\end{array}$ & $\begin{array}{c}\text { Fosfor } \\
\left(\mathbf{( P}_{\mathbf{2}} \mathbf{2 O}_{\mathbf{5}}\right)\end{array}$ & $\begin{array}{c}\text { Potasyum } \\
\left(\mathbf{K}_{\mathbf{2}} \mathbf{O}\right)\end{array}$ & $\begin{array}{c}\text { Organik } \\
\text { Madde }\end{array}$ \\
\hline YUKARI & 31.0 & 0.008 & 7.8 & 1.4 & 12.76 & 154.46 & 1.85 \\
\hline CAMïiKEBíR & 60.9 & 0.03 & 7.7 & 2.1 & 22.0 & 134.98 & 1.26 \\
\hline
\end{tabular}

*Derbent İlçe Gıda Tarım ve Hayvancılık Müdürlüğü’nden (2020) alınmıştır.

\subsubsection{Kolüviyal Topraklar}

$\mathrm{Bu}$ topraklar, yan derelerin kısa mesafelerden taşıyı getirdiği materyaller üzerinde oluşmuştur. Buralarda toprak katları belirgin olmayıp, alt katlarda bünyenin kaba ve orta olması, çakılların kısmen köşeli, eğimin bulunması ve eğimin materyalin geldiği yöne doğru artı̧̧ göstermesi, drenajın iyi olması, organik madde azlığı ve herhangi bir tuzluluğa sahip olmaması sahadaki kolüviyal toprakların başlıca karakteristikleridir. Yer yer alüvyonlara geçiş özelliği görülür. Kolüviyal topraklar dik vadi ve tepe yamaçlarında toprak ve taş molozu olarak da görülürler. Bu toprakların ana materyali ekseriye Üst Miosen- Pliosen'e ait kolüviyonlardan ibarettir (Bozyiğit, 2018:86).

Derbent ilçesinde kolüviyal topraklar; Mülayim Mahallesi’ndeki etek düzünde, Dikmen T. (1762 m) kuzeyinde, Derbent (Fotoğraf 2), Uluçay ve Bağırsak Dere vadilerinde görülmektedir. Buralarda yer yer sulu ve kuru tarım yapılmaktadır.

Kolüvyal topraklar, 3. sınıf arazi olup sığ topraklardır. Bu topraklarda da su erozyonu görülmekte olup kuru tarım yapılmaktadır (Konya İli Arazi Varlığı, 1992).

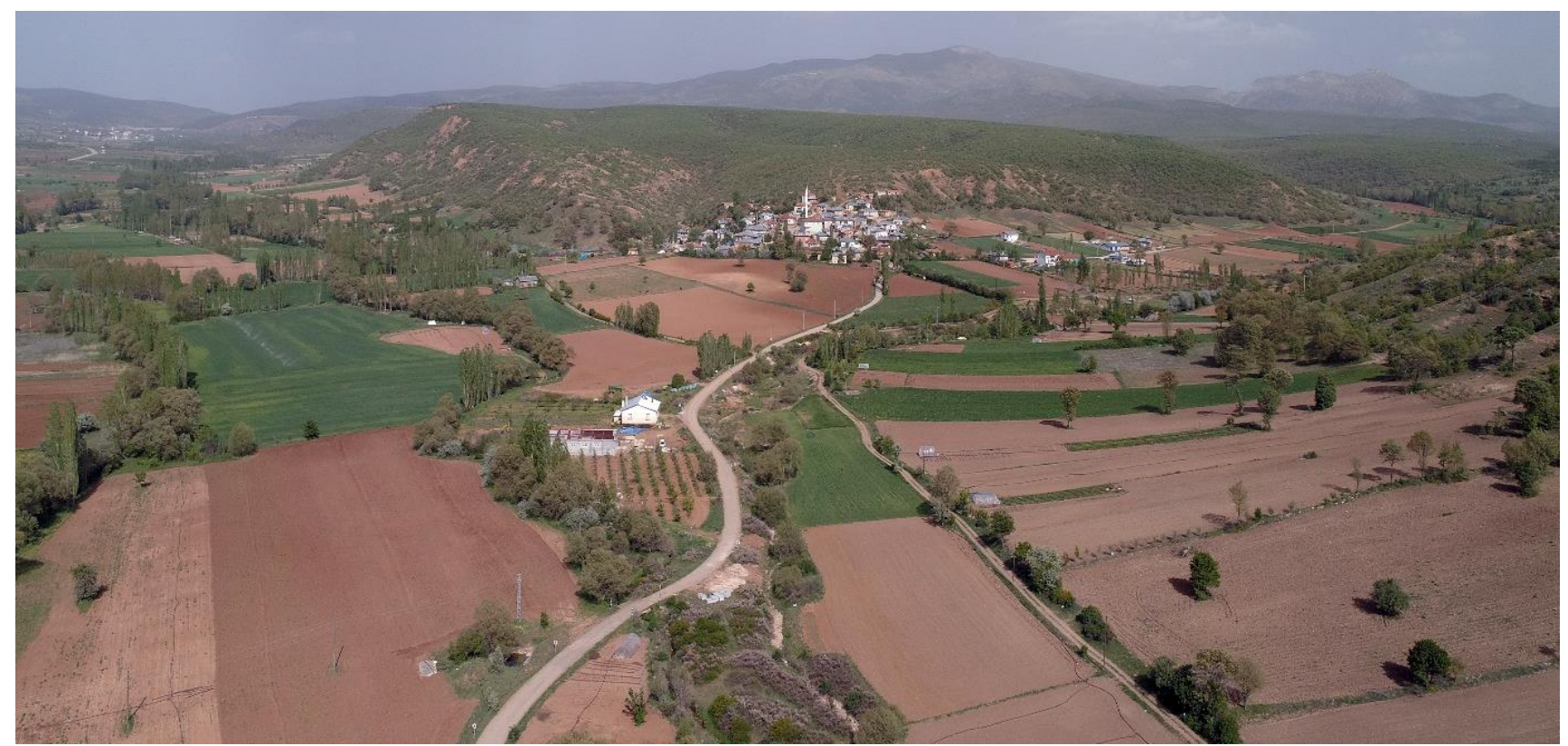

Fotoğraf 2. Derbent Deresi Vadi Tabanı ve Yamaçlarında Alüvyal ve Kolüviyal Topraklar (Süleyman Mahallesi Kuzeyi)

\subsubsection{Kestane Rengi Topraklar}

Bağırsak Boğazı'nın kuzey kesimleri ile Derbenttekke Mahallesi güneyinde, Süleyman Mahallesi'nin kuzeybatısı ile Derbent ilçe merkezinin kuzeydoğusundaki Tasmakıran T.(1856 m) çevresinde görülmektedir. Miosen-Pliosen yaşlı kalker, marn, kumtaşı, kiltaşı ve konglomeralar ile Üst Permien yaşlı kristalize kalker ve mermerler üzerinde gelişme göstermiştir. Profil katlarında kireç birikimleri bulunmaktadır. Genellikle orman ve fundalık olarak kullanılmaktadır.

\subsubsection{Kırmızımsı Kestane Rengi Topraklar}

Derbent ilçesinin hemen her tarafinda görülen toprak tipidir (Fotoğraf 3). Farklı jeolojik birimler üzerinde gelişme göstermiştir. Ana kaya kalker, dolomitik kalker, mermer, kiltaşı, konglomera, marn ve bazik volkanik kayalardan oluşmaktadır. Yol yarmalarında A, B ve C profili ile dikkat çeker. Kırmızı kestane rengi topraklar orman, fundalık ve kuru tarım olarak kullanılmaktadır. 
Bu toprakları karakterize etmesi açısından Güney ve Çiftliközü mahallelerinin farklı yerlerinden alınan toprak örneklerine göre: Güney 1 topraklarının; tınlı, tuzsuz, hafif alkali, kireçli, fosfor ve organik madde miktarları orta, potasyum miktarının yüksek olduğu anlaşılmıştır. Güney 2 topraklarının; tınlı, tuzsuz, hafif alkali, kireçli, fosfor ve potasyum miktarlarının yüksek, organik maddenin az olduğu tespit edilmiştir (Tablo 2). Çiftliközü 1 topraklarının: killi, tuzsuz, hafif alkali, orta kireçli, fosfor miktarı çok az, potasyumun yeterli, organik maddenin az olduğu; Çifliközü 2 topraklarının killi-tın, tuzsuz, hafif alkali, fazla kireçli, fosfor ve organik maddenin az, potasyumun yeterli olduğu anlaşılmıştır.

Tablo 2. Derbent İlçesinin, Farklı Yerlerinden Alınan Toprak Örneklerine Ait Bazı Özellikler*

\begin{tabular}{|c|c|c|c|c|c|c|c|}
\hline $\begin{array}{l}\text { Toprak Örneği } \\
\text { Alınan Yerler }\end{array}$ & Saturasyon & $\begin{array}{c}\text { Toplam } \\
\text { Tuz }\end{array}$ & $\mathbf{p H}$ & $\begin{array}{c}\text { Kireç } \\
\left(\mathrm{Ca} \mathrm{CO}_{3}\right)\end{array}$ & $\begin{array}{l}\text { Fosfor } \\
\left(\mathrm{P}_{2} \mathrm{2O}_{5}\right)\end{array}$ & $\begin{array}{c}\text { Potasyum } \\
\left(\mathrm{K}_{2} \mathrm{O}\right)\end{array}$ & $\begin{array}{c}\text { Organik } \\
\text { Madde }\end{array}$ \\
\hline GÜNEY 1 & 60.9 & 0.03 & 7.7 & 2.1 & 22.0 & 134.98 & 1.26 \\
\hline GÜNEY 2 & 45.0 & 0.01 & 7.8 & 6.4 & 8.35 & 48.60 & 2.09 \\
\hline ÇİFTLÍKÖZÜ 1 & 31.0 & 0.01 & 7.5 & 2.1 & 11.96 & 96.21 & 1.50 \\
\hline ÇİFTLİKÖZÜ 2 & 73.7 & 0.02 & 7.7 & 14.2 & 1.26 & 68.90 & 1.42 \\
\hline
\end{tabular}

*Derbent İlçe Gıda Tarım ve Hayvancılık Müdürlüğ̈’’nden (2020) alınmıştır.

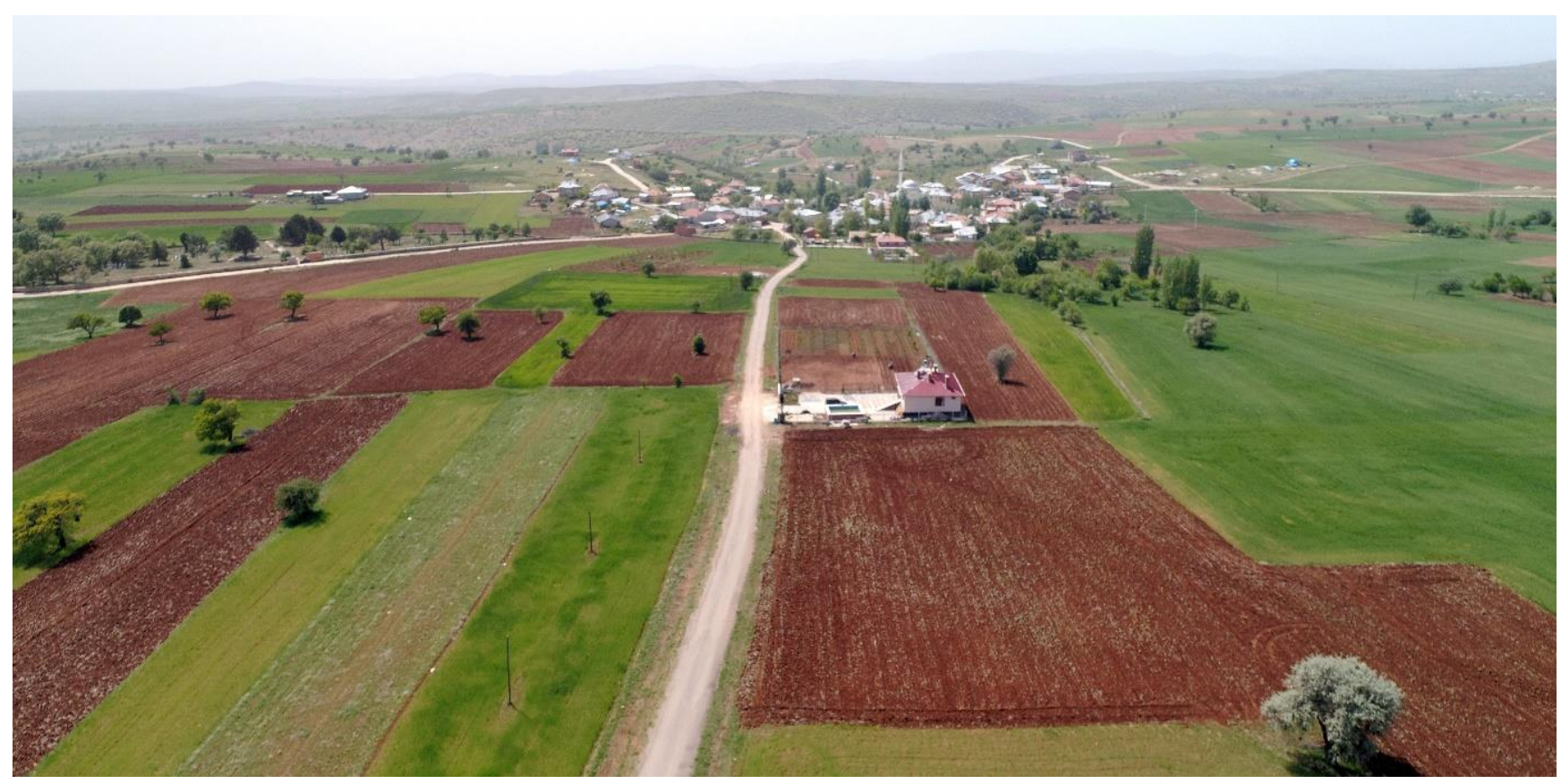

Fotoğraf 3. Değiş Mahallesi Doğusunda Kırmızımsı Kestane Rengi Topraklar

\subsubsection{Kırmızımsı Kahverengi Topraklar}

Kırmızımsı kahverengi topraklar Dikmen Tepe'nin $(1762 \mathrm{~m})$ kuzeydoğusu ile Saraypınar Mahallesi kuzeyinde oldukça sınırlı sahalarda görülür. Ana madde çoğunlukla Alt Orta Trias kalker kumtaşı, konglomera ile Üst Trias-Alt Jura kalkerlerden oluşan depozitlerdir. Bu topraklarda yaygın olan topografya hafif dalgalı veya dalgalı plato yüzeyleridir.

Kırmızı kahverengi topraklarda sığlık en önemli problemdir. Toprak derinliğini kısıtlayan temel faktör erozyondur. Bunu ana maddenin sertliği izler. Genellikle mera ve kuru tarımda kullanılan bu toprakların doğal bitki örtüsü bozkırdır (Bozyiğit, 2018:87). Saraypınar ve çevresinde kırmızımsı kahverengi topraklar IV ve VII. sınıf arazi olup orta derinlikteki taşlı topraklardır. Bu topraklar kuru tarım ve mera alanı olarak kullanılmaktadır.

\subsubsection{Kireçsiz Kahverengi Orman Toprağı}

$\mathrm{Bu}$ topraklar $\mathrm{ABC}$ profilli topraklardır. A horizonu iyi oluşmuş ve gözenekli bir yapısı bulunmaktadır. B horizonunu gözle ayırt etmek zordur. B horizonu bazen kil mineralleri zenginleşmiş halde bulunabilir. Bazen toprak profilinde B horizonu hiç bulunmayabilir. A horizonundan C horizonuna geçiş görülmektedir (Konya İli Arazi Varlı̆̆ı,1992:14).

Kireçsiz kahverengi orman toprakları, Derbent ilçesinin güneyinde Bağırsak Deresi ve çevresinde görülmektedir. Genellikle MiosenPliosen yaşlı tüf, aglomera, ignimbirit, andezit, dasit ve bazalt ana kaya üzerinde gelişme göstermiş̧ir. Genellikle mera ve kuru tarımda kullanılan bu toprakların doğal bitki örtüsü; meşe, karaçam ve ardıç türlerinden oluşan ormandır. 


\subsection{Derbent İlçesi Topraklarının Sorunları}

Derbent ilçesi topraklarının karşı karşıya kaldığı sorunlar arasında erozyon, sulama, toprak sığlığı, eğim, taşlılık ve yanlış arazi kullanımı yer almaktadır.

\subsubsection{Erozyon}

Derbent ilçesinde su erozyonu en önemli problemlerdendir. Yağışlar ile erozyon tipi arasında önemli bir ilişki bulunmaktadır. İlçede özellikle ilkbahar aylarında düşen yağışlar kısa süreli sağanak şeklindeki yağışlar gerek damla erozyonu, gerekse yüzey erozyonu olarak etkili olmaktadır. Güçlü sağanak yağışların başlangıcındaki iri yağmur taneleri damla erozyonunu arttırmaktadır. Ayrıca antropojenik etkilerle bitki örtüsünün tahrip edilmesi su erozyonunu hızlandırmaktadır. Aladağ’ın doğu ve batı yamaçlarında, Bağırsak Dere Vadi yamaçlarında şiddetli su erozyonu görülür.

\subsubsection{Sulama}

Derbent ilçesi topraklarının en önemli sorunlarından biri de sulamadır. Bunda en büyük faktör, yağış azlığıdır. Çünkü Derbent ilçesinin kuzey, doğu ve güneyi dağlarla çevrili olduğu için nemli hava kütleleri içeriye sokulamamaktadır. Ayrıca yıllık yağış miktarının düşük olması, mevcut akarsuların debileri düşük periyodik özellik göstermesi sulama sorununu doğurmaktadır. İlçede toplam tarım arazilerinin (138 000 dekar), \%20.28'i(28.000 dekar) sulanabilir olması problemin boyutunu gözler önüne sermektedir. Bugüne kadar tarımsal üretimde karşılaşılan bu problemin ortadan kaldırılması için Dereağzı Göleti başta olmak üzere Alişar, Çiftliközü ve Süleyman göletleri yapılmış ancak sulama sorununu çözememiştir. Bu durumda yeni göletlerin acilen devreye sokulması gerekmektedir.

\subsubsection{Toprak Sığlığı veya Derinlik}

Çalışma sahasında derinliği kısıtlayan en önemli faktör erozyon olup, bunu ana kaya sertliği izler. Derbentte yağışın az olması, yazların sıcak ve çok kurak geçmesi toprak oluşumunu fiziksel ve biyolojik yönden kısıtlar. Engebeli ve plato sahalarında yer alan Değiş, Derbenttekke, Saraypınar, Arapözü mahallelerine ait arazilerdeki toprakların derinliklerinin az olduğu dikkati çekmektedir. Bu durum ekimi ve dikimi yapılan bitkilerin gelişme ve büyümelerini önemli derecede engellemektedir.

\subsubsection{Eğim ve Taşılıık}

Derbent ilçesinin doğu kesiminde kuzeyden güneye doğru Tasmakıran T.(1856 m), Aladağ (2339 m) ve Sarı T.(2040 m) yer almaktadır. Bu yüksek kesimin batıya doğru uzantısını Dikmen T.(1762 m) oluşturmaktadır. Bu kesimlerde eğim $11^{\circ} 18^{\prime} 35^{\prime \prime}$ ile $30^{\circ} 57^{\prime}$ 49" arasında değişmektedir. Ayrıca Bağırsak Deresi'nin vadi yamaçlarında da eğim yer yer $11^{\circ} 18^{\prime} 35^{\prime \prime}$ dereceyi bulmaktadır. Yüksek eğimli arazilerdeki toprakların erozyonla kaybedildiği sonucuna ulaşılmıştır.

Eğim şartlarındaki olumsuzluklara ek olarak taşlılık ta, toprak işlenmesine ve bitki gelişmesine zarar vermektedir. Taşlılık problemi Değiş, Derbenttekke, Çiftliközü, Saraypınar (Fotoğraf 4) ve Arapözü mahallesi topraklarında görülmektedir.

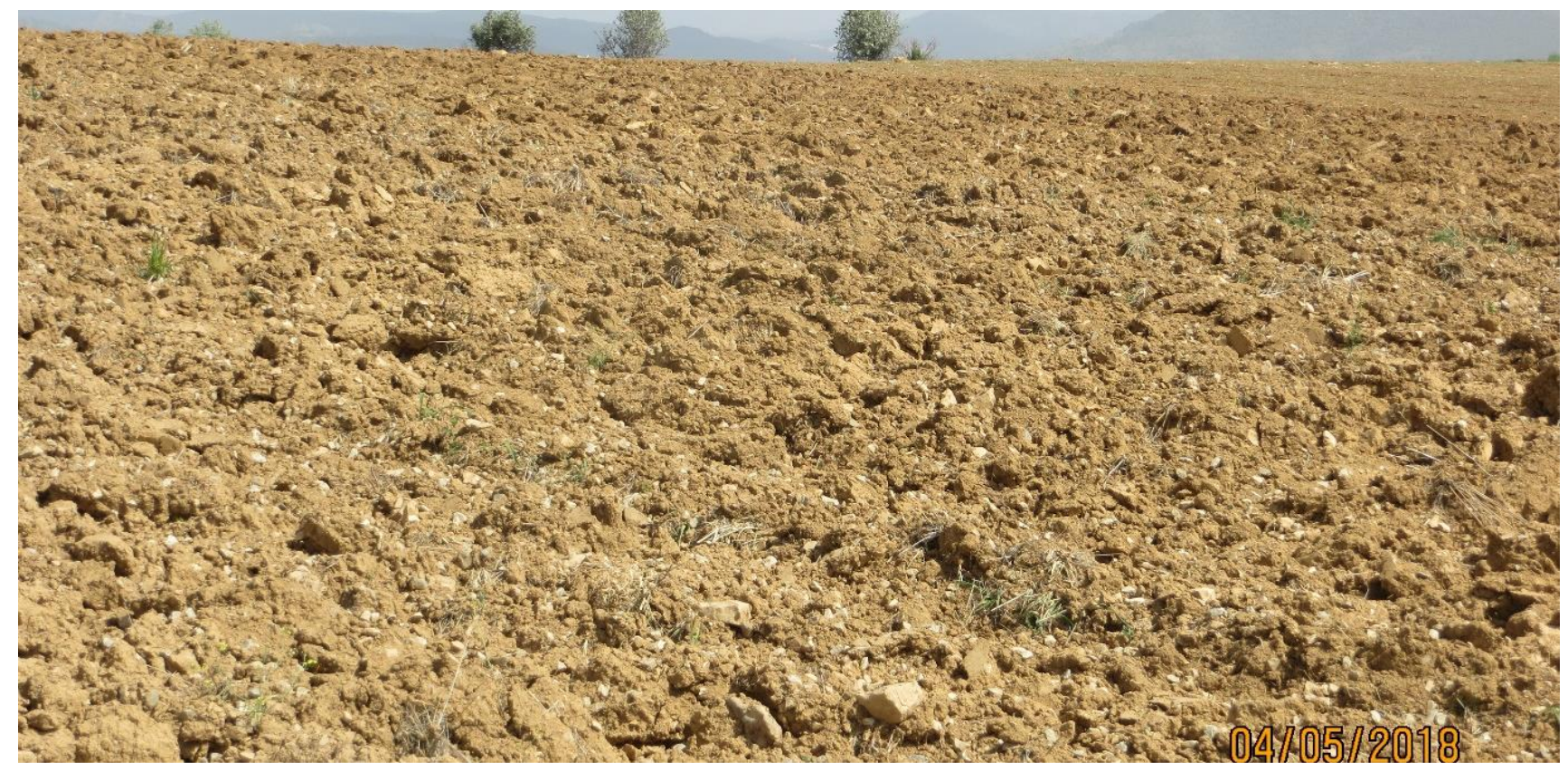

Fotoğraf 4. Derbent İlçesi Topraklarında (Saraypınar Mahallesi Doğusu) Taşlılık Önemli Bir Problem Olarak Dikkati Çekmektedir. Taşlılık Toprakların İşlenmesini Zorlaştırmakta ve Ürün Kaybına Neden Olmaktadır. 


\subsubsection{Yanlış Arazi Kullanımı}

Derbent ilçesi topraklarını tehdit eden bir diğer sorun insan kaynaklı yanlış arazi kullanımıdır. Yanlış arazi kullanımında başta doğal bitki örtüsünün farklı nedenlerle tahribi söz konusudur. Mevcut şartlarda orman veya fundalık olarak kullanılması gereken sahaların, genellikle tarım alanlarına dönüştürüldüğü görülmektedir (Fotoğraf 5). Yanlış arazi kullanımının bir diğer örneği ise nadasa bırakılan sahaların çokluğudur. Derbent ilçesinde yağış ve sulama yetersizliğinden dolayı tarım topraklarının \%33.1'i (41 200 dekar) nadasa bırakılmakta, bir kısmında ise kuru tarım yapılmaktadır. Bu durum toprakların sığ olmasına ve verimli kısmının sürekli taşınmasına neden olmaktadır. İlçe topraklarının özelliklerine göre kullanılmaması, çiftçilerin eğitimsizlikleri ve hasat sonrası tarlada kalan anızların sürülmeyip yakılması gibi yanlış uygulamalar toprak sorunlarını arttırmaktadır.

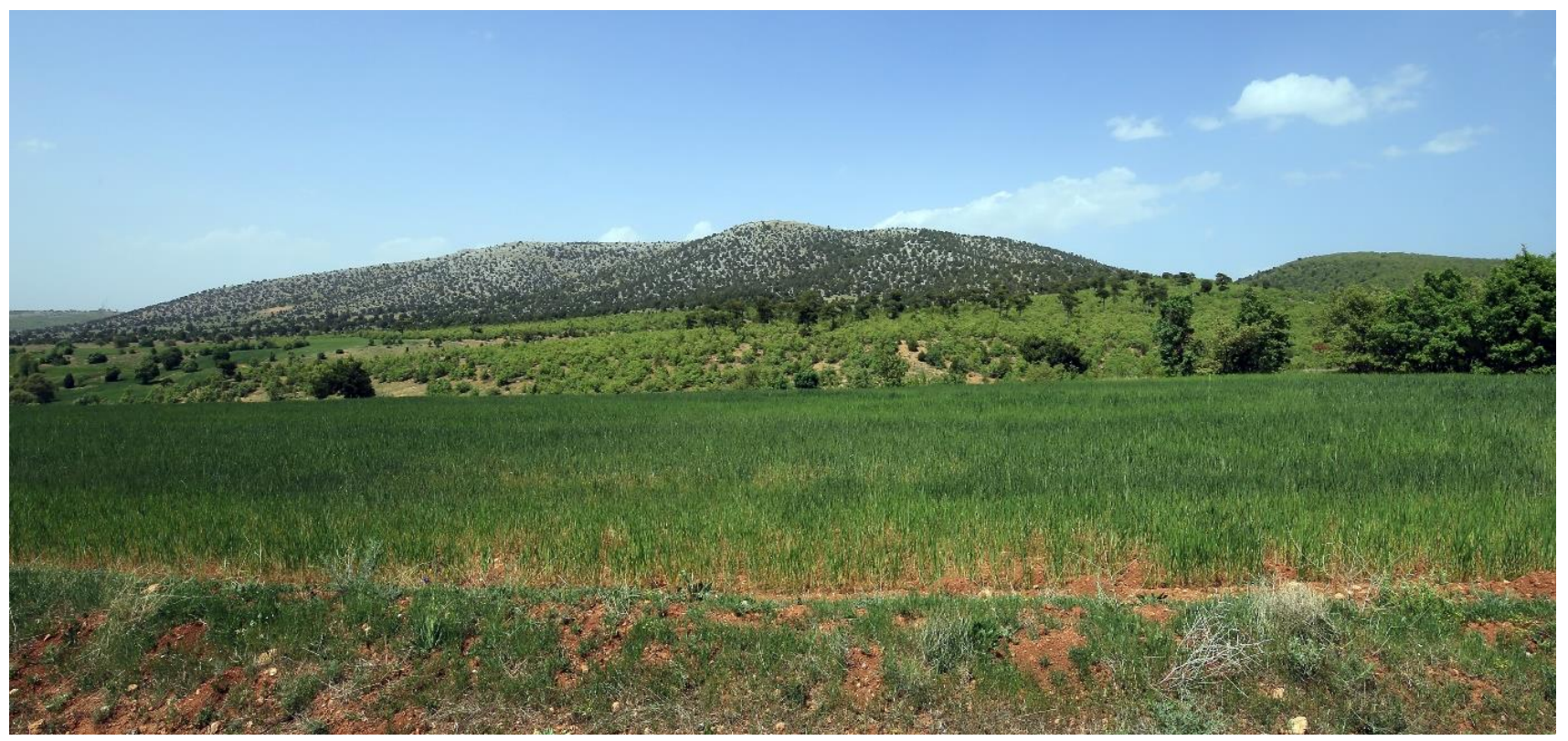

Fotoğraf 5. Doğal Bitki Örtüsünün Tahribi Sonucunda Ortaya Çıkmış Sekonder Vejetasyonun Tahrip Edilmesi ile Tarıma Açılmış Ĕğimli Sahalar(Derbenttekke-Değiş Mahalleleri Arasındaki Alçak Tepelik Sahasının Güney Yamaçları)

\section{Sonuç}

Derbent ilçesi toprakları, pedogenetik özelliklerine göre yapılan sınıflamada üst kategori tasnifine tabi tutulmuştur. Buna göre yörede altı büyük toprak grubu yer almaktadır. Bu topraklardan en yaygın olanı, kırmızımsı kestane rengi topraklarıdır. Bunu kestane rengi, kireçsiz kahverengi orman, kolüvyal, alüvyal ve kırmızımsı kahverengi toprakları takip eder. Yöre topraklarının oluşumunda ana kaya, iklim ve topoğrafyanın etkileri görülmektedir. Volkanitlerin yaygın olduğu sahalarda kireçsiz kahverengi orman, kireçtaşının yaygın olduğu yerlerde kırmızımsı kestane rengi toprakları, topoğrafyanın düz veya hafif eğimli yerlerinde alüvyal ve kolüvyal topraklar yer alır. Organik madde bakımından fakir olan topraklarda en yüksek değere, Güney Mahallesi topraklarında (2.09) rastlanmaktadır.

Derbent ilçesinin farklı yerlerinden alınan toprak örneklerinin laboratuvar analizlerinde: saturasyon \%31-73.7, toplam tuz 0.00-0.03, $\mathrm{pH}$ 7.5-7.8, kireç $\left(\mathrm{CaCO}_{3}\right)$ 1.4-15.2, fosfor $\left(\mathrm{P}_{2} 2 \mathrm{O}_{5}\right)$ 1.26-22.0, Potasyum $\left(\mathrm{K}_{2} \mathrm{O}\right), 48.60-154.46$ organik madde 1.26-2.09 arasında değişmektedir. Elde edilen veriler ışığında Derbent ilçesi topraklarının: tınlı, killi-tınlı ve killi; tuz oranı az; pH: hafif alkali; kireç: kireçli, orta kireçli; fosfor: çok az, az, orta, yüksek, çok yüksek; potasyum: yeterli, yüksek; organik maddenin ise az olduğu sonucuna ulaşılmıştır(Derbent İlçe Gıda Tarım ve Hayvancılık Müdürlüğü, 2020). Bölgedeki akarsular tarafından teşekkül ettirilen alüvyal toprakların genelde tınlı ve killi tın bünyeye sahip oldukları, geçirgenlikleri yeterli, su tutma kapasitelerinin iyi, tuzluluk probleminin ise olmadığ 1 anlaşılmaktadır. Ayrıca alüvyal toprakların toprak derinliği çok yıllık bahçe bitkileri ve tarla bitkileri yetiştiriciliğine uygun topraklardir.

İlçe topraklarında tespit edilen organik madde eksikliği, pH yüksekliği ve kireç miktarının fazlalığı mikro besin elementi ve azot eksikliğinin ortaya çıkmasına sebep olmaktadır. Yörede yetiştiriciliği yapılan ve yapılması düşünülen bitkilere makro ve mikro besin elementi takviyesi yani gübreleme yapılması zorunludur. Bu konuda amonyum sülfat, üre, potasyum sülfat ve diamonyum sülfat önerilmektedir. Kil oranı yüksek araziler de drenaj sorunu da görülebileceğinden bahçe kurulumu öncesi drenaj sorununun giderilmesi gerekir.

Derbent ilçesindeki kolüvyal topraklar etkili toprak derinliği genellikle sı̆̆g, organik maddece zayıf; fosfor, azot gibi makro besin elementlerince zayıf, kireç miktarı fazla topraklardır. Bu arazilerde bitkisel üretim verimini arttırmak için toprak strüktürünü geliştirici uygulamalar yapılmalı, özellikle organik maddenin arttırılması için yanmış ahır gübresi, humik asit vb. organik gübre takviyesi gerekir. Sı ̆̆ toprak derinliği olan arazilerde ağaç dikimi yapmadan önce derin fidan çukurları açılarak fidan dikimi sonrası bu çukurlar toprakla doldurulmalı; eğimli yamaç arazilerde teraslama uygulaması yapılarak kullanılmalıdır. Analiz sonuçlarına göre bu araziler yüksek kireç oranı içerdiğinden ve $\mathrm{pH}$ değerleri bazik karakterde olduğundan söz konusu arazilerde azot eksikliğini gidermek için amonyum sülfat gibi asidik karakterde gübreler kullanılması önerilebilir. 
Derbent ilçesi topraklarını tehdit eden süreçler arasında; erozyon, sulama, sığlık, eğim, taşlılık, yanlış arazi kullanımı olduğu anlaşılmıştır. Bu problemlerden sulama suyu, erozyon ve yanlış arazi kullanımı daha ön plana çıkmaktadır.

Derbent ilçesi topraklarının en önemli sorunu, sulama suyu problemidir. Tarım topraklarının ancak \%20,28'inin sulu, \% 79.72'inin ise kuru tarım olarak kullanıldığı tespit edilmiştir (TÜIK, 2016; T.C.Derbent Kaymakamlığı, Derbent İlçe Gıda Tarım ve Hayvancılık Müdürlüğü, 2017). Bu durum yöre insanının geçim kaynaklarını kısıtlamakta, yaşam alanlarını terk etmelerine neden olmaktadır. Yağış ve yüzeysel suların yetersizliği sebebiyle sulama suyu temini için mevcut sulama göletlerinin arttırılması gerektirmektedir.

İlçe topraklarını tehdit eden bir diğer faktör ise su erozyonudur. Yörede su erozyonunun farklı türleri görülmekle birlikte yüzey ve akarsu erozyonunun daha etkili olduğu görülür. Derbent ve Bağırsak derelerinin vadi yamaçları ile Akdağ dağlık kütlesinin eğimli yamaçları şiddetli su erozyonuna uğramış kesimlerdir. Bu konuda baraj ve ağaçlandırma çalışmaları sürdürülmesi önerilmektedir.

Derbent ilçesinde 13 mahalle, 11 yayla yerleşmesi bulunmaktadır. Mahalle ve yayla yerleşmelerinin bir kısmı orman içi veya orman yakınında yer almaktadır. Bu mahalle ve yaylalarda yaşayan halkın yakacak temini, hayvan otlatmak ve tarım faaliyetlerinden doğal bitki örtüsü zarar görmektedir. Bu durumda mera alanlarının kontrollü otlatılması, ahır hayvancılığının yaygınlaştırılması ve halkın yakacak ihtiyacını başka yollardan karşılanması gerekmektedir.

Sonuç olarak Derbent ilçe halkına, öncelikle yörenin toprak potansiyeli kavratılmalı, daha sonra da bu değerleri koruyarak kullanma yolu öğretilmelidir.

\section{Kaynakça}

Akalan, İ. (1983), Toprak Bilgisi, Ank., Üniv., Ziraat Fak., Yay no:878, Ankara.

Atalay, İ. (2011), Toprak Oluşumu, Sinıflandırması ve Coğrafyası, (5.Bask1), Meta Basım Matbaacılık Hizmetleri, İzmir.

Atalay, İ.-Gökçe Gündüzoğlu, A. (2015), Türkiye'nin Ekolojik Koşullarına Göre Arazi Kabiliyet Sinıflandırmasl, Meta Basım Matbaacılık Hizmetleri, İzmir.

Bağdatlı, M.C.-İstanbulluoğlu, A.-Bayar, N.A. (2014), Toprak ve su Kaynakları Potansiyelinin Coğrafi Bilgi Sistemleri (CBS) Yardımıyla Belirlenmesi: Tekirdağ-Çerkezköy İlçesi Uygulaması, Afyon Kocatepe Üniversitesi, Fen ve Mühendislik Dergisi, Say1:14, 17-25, Afyon.

Baldwin, M-Kellog, C.E.-Thord, J. (1938), Soil Clasification. Soil and Man, U.S. Dept. Agric. Ybk 979-1001 pp.illus.

Bozyiğit, R.-Kaya, B.(2017), Altınapa Barajı Havzası'nda (Konya) Erozyon ve Önlemler, Marmara Coğrafya Dergisi, Sayı 36, s.285303, İstanbul.

Bozyiğit, R. (2018), Takkeli Dă̆, Çizgi Kitabevi Yayın no:834, Konya.

Crocker, R.L. (1952), The plant factor in soil formation Australia., J.Sci. 21, 180-193.

D.M.İ.,Gn.M. (2016): Derbent ve Beyşehir Meteorolojik İstasyonlarına Ait:

*Yıllık Meteoroloji Bültenleri.

*Günlük ve Aylık Meteoroloji Bültenleri.

Dokuchaev, V. V.,(1883), Russian Chernozem. Israel Program for Scientific Translations Ltd. (for USDA-NSF), S. Monson,

Dokuchaev, V.V. (1886), The Russian Stepppes., Dept. Agric. Min. Of Crown Domains fort he World's Columbian Exposition St. Petesburg, Rusia.

Efe, R. (1999), Güney Marmara Bölümü Batısında Toprak Oluşumunu Etkileyen Coğrafi Faktörler ve Toprak Özellikleri, Türk Coğrafya Dergisi, Say1 34, 193-209, İstanbul.

Efe, R.(2000), Biyocoğrafya, MKM Yayınc1lı,, Bursa.

FAO-UNESCO, (1971-1981), Soil map of the world. 1: 5000 000. Volume I. Legend. Prepared by the Food and Agriculture Organization of the United Nations. Unesco - Paris.

Jeny, H. (1941), Factors of Soil Formation A System of Quantitave Pedology, Dover Publications, Inc., New York.

Marbut, C.F.(1927), A Scheme for Soil Classification, First International Congress. Soil Scien, Protect 4, 1-31

Mater, B.,(1998): Toprak Coğrafyası, Çantay Kitabevi, İstanbul.

Mückenhausen, E.(1962), Enstehung, Eigenschaften und Sistematik der Boden der Bundersrepublik Deutschland. Frankfurt.

Özdemir, S.(1997), Temel Ekoloji Bilgisi ve Çevre Sorunları, Hatiboğlu Yayınevi, Ankara.

Şenel, M.-Dalkıııç-H.(2016), 1/100 000 Türkiye Jeoloji Haritaları Serisi, Konya-M 27 Paftası No:227, Maden Tetkik Arama Genel Müdürlüğü, Jeoloji Etütler Dairesi, Ankara.

Şenel, M.-Pehlivan, N.(2016), 1/100 000 Türkiye Jeoloji Haritaları Serisi, Konya-M 28 Paftası No:228, Maden Tetkik Arama Genel Müdürlüğ̈̈, Jeoloji Etütler Dairesi, Ankara.

Tarım ve Köy İşleri Bakanlığı, Köy Hizmetleri Müdürlüğü, (1992), Konya İli Arazi Varlığı, Ankara.

T.C.Derbent Kaymakamlığı, Derbent İlçe Gıda Tarım ve Hayvancılık Müdürlüğü, (2017), Faaliyet Raporu, Derbent.

T.C.Derbent Kaymakamlığı, Derbent İlçe Gıda Tarım ve Hayvancılık Müdürlüğü, (2018), Faaliyet Raporu, Derbent.

T.C.Derbent Kaymakamlığı, Derbent İlçe Gıda Tarım ve Hayvancılık Müdürlüğü, (2020), Toprak Analiz Raporları, Derbent.

TÜİK (2016): Tarım İstatistikleri, www.tüik.gov.tr/Erişim 19 Nisan 2018.

TÜIK (2020): Nüfus İstatistikleri, www.tüik.gov.tr/Erişim 07 Mayıs 2020. 